DOI: $10.7819 /$ rbgn.v15i48.1398

Subject Area: Organizational Strategy and Behavior

\title{
Institutional and Strategic Influences on IT Architecture Decisions: comparative case studies in Brazilian companies
}

\author{
Influências Institucionais e Estratégicas em Decisões de Arquitetura de TI: estudo \\ de casos comparados em empresas brasileiras
}

\section{Influencias Institucionales y Estratégicas en la toma de Decisiones de la Arquitectura de TI: estudio de casos en empresas brasileñas}

\author{
Chen Wen Hsing ${ }^{1}$ \\ Cesar Alexandre Souza ${ }^{2}$
}

Received on August 5, 2012 / Approved on September 24, 2013

Responsible Editor: João Maurício Gama Boaventura, Dr.

Evaluation Process: Double Blind Review

\begin{abstract}
The aim of this paper is to examine the influences on IT architecture decisions by viewing it through the lens of Institutional Theory and of Strategic Choice Theory, using the comparative case studies. Institutional influence can be the result of an external action or of something internal within the organizational, whereas strategic influence is related to the voluntary behavior of managers. The case of a large-scale company, where there is extensive internal policy formalization, was compared to a midsize company with a less mature architecture level. In spite of their differences as to the use of IT architecture, similar findings appeared in both organizations concerning these two influences. Both types of influence act together: the strategic
\end{abstract}

type was most mentioned during interviews, whereas the institutional type appeared in decisions related to innovation and risks.

Keywords: Institutional theory. Information technology architecture. Strategic choice theory.

\section{RESUMO}

Esta pesquisa tem como objetivo examinar as influências sobre as decisóes de arquitetura de TI sob as lentes da Teoria Institucional e da Teoria da Escolha Estratégica por meio de estudos de casos comparados. A influência institucional pode ser proveniente de uma ação externa ou de algo interno à organização, ao passo que a influência estratégica está relacionada com a ação voluntária dos gestores. $\mathrm{O}$ caso de uma empresa

1. Doctoral student at the University of São Paulo - College of Economy, Administration and Accounting (FEA/USP).

2. Doctor in Administration and Professor at the University of São Paulo’s College of Economy, Administration and Accounting (FEA/USP).

Authors’ address: Av.Prof. Luciano Gualberto, 908 - São Paulo, SP, CEP 05508-010 - Brazil 
de grande porte, que possui maior formalização de suas políticas, foi comparado com o de outra de médio porte, que está em um estágio de maturidade de arquitetura menos avançado. As duas organizaçóes, apesar de haver diferenças em relação ao uso da arquitetura de $\mathrm{TI}$, apresentaram resultados semelhantes relacionados à atuação dessas duas influências. Ambas as influências agem em conjunto: a estratégica foi a mais mencionada pelos entrevistados e a institucional apareceu pontualmente em decisóes que envolviam inovação e riscos.

Palavras-chave: Teoria institucional. Arquitetura de tecnologia de informação. Teoria da escolha estratégica

\section{RESUMEN}

A partir de la Teoría Institucional y de la Teoría de la Elección Estratégica se realiza un estudio de casos para examinar las influencias institucionales y estratégicas en la toma de decisiones sobre la arquitectura de la tecnología de información. La influencia institucional puede provenir de una acción externa o interna de la organización, mientras que la influencia estratégica está relacionada con la acción voluntaria de los gerentes. Se comparó el caso de una gran empresa con un nivel superior de madurez de arquitectura de TI con el de una organización de tamaño medio. Aunque hay diferencias en el uso de la arquitectura de TI, las influencias actúan de forma parecida en ambas empresas. Los entrevistados citaron razones estratégicas más frecuentemente en sus respuestas, mientras que las influencias institucionales actuaron sobre decisiones de innovación y riesgo.

Palabras clave: Teoría institucional. Arquitectura de la tecnología de información. Teoría de la elección estratégica.

\section{INTRODUCTION}

Key decisions in the field of information technology (IT) can be classified under five categories: principles, architecture, infrastructure, applications and investments (WEILL, ROSS, 2004). IT architecture is an important aspect in constantly changing environments that must be agile when building new systems that meet business needs. Amongst potential benefits arising from the adequate construction and management of IT architecture are the ability to efficiently share information as to business processes, the ability to respond quickly to changes in technology that result from business needs, a reduction in IT costs due to economies of scale, standardization and sharing of resources (UNITED STATES, 2004).

A considerable part of IT research focuses on design, implementation and use of artifacts that represent tangible solutions to real problems. Consequently, striving for theoretical foundations in fields of knowledge outside the scope of technology contributes to theoretical and practical enrichment around the topic, by integrating IT knowledge fields and organizational studies. One possibility is neoinstitutionalist theory, particularly Powell and DiMaggio's (1991), which emerged as a counterpoint to theories that addressed organizational managers and organizations as rational actors, such as the Strategic Choice Theory (CHILD, 1997; MILES et al., 1978). By including Institutional Theory in the research of information technology, one is able to develop a more structural and systemic understanding of how technology is intertwined in complex interdependent social, economic and political networks (ORLIKOWSKI, BARLEY, 2001).

Thus, this paper aims at analyzing the influence of institutional and strategic decisions on IT architecture. Institutional Theory and Strategic Choice Theory will be used as separate lenses to observe different decisions made by managers. The empirical part of the study consists of comparative case studies carried out in a company with formalized IT architecture management, and another facing early stages of formalization. The secondary objectives of this paper are as follows: 1) to identify the meaning of IT architecture to managers of organizations surveyed; 2) to check if institutional or strategic factors are prevailing 
influences in justifications presented by managers for IT architecture decisions considered important to organizations; 3) to check for differences between the two organizations as to prevailing influences.

According to Ross, Weill and Robertson (2008), IT architecture is a key element in the maintenance of business strategies, since they found that companies with more mature architectures were more successful in achieving strategic goals and higher than average returns on invested capital.

Thus, the process of decision making in IT architecture and its implications for the organization must be investigated. Although the topics governance and IT architecture count on a reasonable amount of published studies, most of them present normative models for their implementation; only a few strive to ascertain how decision making processes do actually occur on IT architecture in business reality (RADEKE, 2010). We searched for articles published since 2007 in Thomson Reuters' Web of Science (2013) under expressions "enterprise architecture" combined with "decision", "factor" or "influence" under categories referring to IT and management. "Enterprise Architecture" is used in references. From the remaining 101 articles on, we carried out classification according to abstracts. Amongst the latter, there were 79 about tools in normative/prescriptive models and seven weren't about the topic. Since this article is focused on descriptive and not normative analyses, they were all excluded; that is, the study is interested in the way that decisions actually occur and not in the way in which they should be made. Fifteen articles remained describing some aspect of IT architecture and, amongst them, seven investigated the results of these initiatives; others described tools and techniques, but none described the decisions made, as discussed in this research. Therefore, there is a lack of research in this area.

Our proposed contribution is to identify whether there are differences in the justifications of decisions in the management of IT architecture in typical companies facing different stages of maturity: a large one whose staff is dedicated full time to this activity, and another midrange one being formalized. Another contribution is to examine the influences on architectural decisions from the point of view of Institutional Theory and Strategic Choice Theory. That is, we want to investigate whether economic rationality, or the pursuit of efficiency, are actually more important than normative rationality, or seeking legitimacy, given that studies indicate that strategic motivations are generally the most mentioned by managers instead of institutional ones (OLIVER, 1988). On the other hand, under a practical viewpoint, this research illustrates architecture management through cases and elucidates aspects of decision making in order to contribute to organization managers' clear definition of priorities.

Over the next sections, we present theoretical framework, methodology employed in the study, case studies, analysis and, finally, conclusions.

\section{THEORETICAL REFERENCES}

\section{I Information technology architecture}

IT Architecture (or enterprise architecture) does not have a universally accepted definition. Definitions found in literature suggest various ideas associated with it: planning, governance, innovation, vision, principles, standardization, integration, policies and service for business strategy (LEGANZA, 2007; ROSS, WEILL, ROBERTSON, 2008; ZACHMAN, 1997). Smolander (2002) found four uses of the term IT architecture as metaphors in the context of systems development, observing that there are different connotations for different groups of people: IT architecture as a plan (describes the structure of the system to be implemented); as literature (referring to documents and references 
for future readers); as language (language standards for sharing the concept of the system and ensuring common understanding); and as a decision (basing decisions on systems).

A definition that is widely used in studies of IT management is that of Ross, Weill and Robertson (2008). They define IT architecture as the organizing logic for applications, data and infrastructure technology embodied in a set of policies and technical choices, whose intention is to enable the company's business strategy. Also according to these authors, IT architecture includes four dimensions: business architecture, information architecture, application architecture and technology architecture.

Business architecture is characterized by activities or tasks that make up major business processes. Information architecture consists of tools that adapt data resources to information needs. Application architecture defines how applications carry out data management and provide information to people who perform business functions. Finally, technology architecture defines the types of technologies or platforms that will support the business in a data sharing environment.

Tamm et al. (2011) carried out a literature review of measures for assessing the quality of IT architecture: use of consultants, top management support, acceptance of stakeholders and obtaining financial resources. They also raised benefits and classified them under four facilitating elements for obtaining benefits, which, in turn, trigger other additional benefits:

- organizational alignment triggers internal consensus, consensus with external agents, conflict resolution, improved customer relationships;

- availability of information triggers improvement of information flow, reducing time and facilitating the decision making process;

- optimization of resources triggers cost reduction, standardization, definition of criteria for outsourcing and quality;
- support of resources for obtaining results triggers improvement in performance, speed, reusability, agility and integration.

Another more specific literature review about the factors that lead to the adoption of SOA (Service Oriented Architecture), by MacLennan and Van Belle (2013), separated the factors into three groups:

- Technology: compatibility, security, performance, standardization, flexibility.

- Organization: cost reduction, organizational culture, efficiency.

- Environment: encouraging industry and partners, support from suppliers.

\subsection{IT architecture management}

Ross, Weill and Robertson (2008) evaluated management strategies for the architecture of dozens of large companies in various countries, classifying them into four stages of maturity as to their degree of development and control:

- Business silos architecture Companies seek to maximize the needs of functional units independently, causing fractioning and nonintegration of the various initiatives of existing systems in the company.

- Standardized technology architecture Seeking efficiency through standardization and centralization of management technology.

- Optimized core architecture Standardization of data and processes occur in the company as a whole.

- Business modularity architecture Companies manage and reuse components freely, according to the needs of business processes, in order to preserve global standards and enable local differences.

In the silo business stage, applications serve individual business needs and are evaluated 
according to the return on investment individually, since local business leaders are the ones who define applications. In the standardized technology stage, there is the implementation of standardized technology platforms, whose main objective is to reduce IT costs. Leaders of business units and IT applications define this stage. Next, in the optimized core stage, IT is focused on processes or shared data, in order to provide business operations' quality. Senior management and process leaders define applications. Finally, the business modularity stage presumes that modules enable business processes so as to provide speed and strategic agility. Senior management, IT leaders, process managers and local leaders define applications.

Ross, Weill and Robertson (2008) found in their research that only $6 \%$ of companies were in the fourth stage of maturity (modularity) - whereas $34 \%$ were in the third stage (optimized core), $48 \%$ in the second stage (standardized), and $12 \%$ in the initial stage (silos). IT architecture practices evolve according to the stage of maturity. Initially, within business silos, financial justification and project methodologies to optimize locally are sufficient. Whilst standardization is occurring, formal review processes and centralized decisions are adopted. When IT starts to receive greater attention from strategic areas and areas referring to processes, there is greater executive participation and full time IT architecture teams are established.

Regarding the IT architecture decision making process, Pulkkinen (2006) points out that, despite it being divided into four hierarchical dimensions (business, information, application and technology), decisions do not have to occur sequentially (first defining business architecture, and then information, application and, finally, technology), since, for example, technology architecture may allow changes in business architecture.

The author then proposes to divide each of the four dimensions into three levels of abstraction, also hierarchical: the organization level, the domain level (representing business units, processes or departments), and the individual information systems level. Thus, one can interpret these three levels as a way of classifying the type of impact, from the broadest in scope, at the competitive organizational level, to the most restricted, at operational level.

Finally, one must consider the importance of role models for the management of company architecture. These models provide guidelines for defining and implementing architecture and its management processes - a fact which, in principle, can help make this process more secure and well defined. When applying these models, companies should consider that they most likely will need to be adapted or combined, according to the company's needs. As will be discussed in the next section, there are strategic and rational motivations for adopting these practices, but their indiscriminate adoption could be evidence of exogenous pressures to obtain legitimacy.

\subsection{Institutional Theory and Strategic Choice Theory}

Institutional Theory and Strategic Choice Theory were chosen as lenses to analyze IT architecture decisions in this paper, because they reflect two human behaviors that contrast determinism and voluntarism, and that are usually placed in opposing groups by various organizational theories' classifications (DESANCTIS, POOLE, 1994; OLIVER, 1997; VICENTE-LORENTE, ZÚNIGA-VICENTE, 2006). The two categories of influences can be considered antagonistic, according to Hrebiniak and Joyce (1985).

According to Zucker (1987), there are two definitions of the term "institutional", which can be a rule concerning a social fact with external action and an organized standard, or something embedded in the formal structures that is not attached to specific stakeholders or situations. Although Institutional Theory is not a single school of thought, its guideline states that organizations adopt new institutional practices by seeking social legitimacy and not 
necessarily because of the rational pursuit of efficiency. DiMaggio and Powell (1983) identified three mechanisms through which institutional influences may occur:

- Coercive-Result of political influences and a legitimacy problem. Formal or informal pressures made by other organizations because of dependency or cultural expectations.

- Mimetic - Result of a default response to uncertainty. The use of management models is an example of this, which can be spread either directly or unintentionally by employee turnover, by consulting firms or by trade associations.

- Normative - Associated with professionalization, and that can be interpreted as the struggle of the collective members of an occupation to define work conditions and methods.

Jobs also suffer coercive and mimetic pressures. Two aspects are source of isomorphism: formal education legitimized by university knowledge base and professional networks for model diffusion. Another mechanism for normative strengthening is the staff filter established by restricted methods of recruitment and career promotion criteria within organizations. These definitions were used when pursuing institutional factors in the case studies and, operationally, are be the factors identified with the support of Institutional Theory.

However, according to the Strategic Choice Theory, strategic factors determine choices that those in power within organizations make in the course of strategic actions. To Child (1997), decision making extends to the environment in which the organization operates, under performance standards that must be evaluated facing economic pressures and the design of the organizational structure itself.

Miles et al. (1978) argue that organizational behavior is only partially predetermined by environmental conditions, and that choices by top management are critical determinants of organizational structure and processes. Although business choices are many and complex, Miles et al. (1978) proposes that they can be viewed as responses to three groups of organizational adaptation issues, which operationally are the factors that have been raised in the case studies through the Strategic Choice Theory:

- entrepreneurship issue - acceptance by managers of a specific product and market domain through commitment of resources;

- engineering issue - involving the creation of a technical or organizational system that solves the entrepreneurship issue;

- management issue - involves reducing the organizational system's uncertainty or rationalizing and stabilizing activities, to solve the entrepreneurship and engineering issues faced by the company.

\section{METHOdology}

This is a qualitative, exploratory and descriptive paper, and it uses the case studies method. Generally, case studies are the preferred strategy when the questions are "how" and "why", since, in this situation, the investigator has little control over events and focus is on the current event, within the context of real experience (YIN, 2003). Thus, this method meets the objectives of this research, since the intention is to identify how institutional and strategic factors influence the process by which organizations decide on IT architecture. Two cases were used to make it possible to check if there are noticeable differences between companies with different degrees of IT architecture management maturity. To Yin (2003), multiple case studies resemble the replication of experiments in which cases must be selected to predict similar results or produce contrasting results. 
The organizations studied should be representative cases of companies with private capital participation, possessing some kind of IT architecture policy, whether formal or informal. Moreover, since the goal is to compare companies in different levels of maturity, a company that is more advanced in policies and other that is less mature or less formalized are the ones that best fit the profile of the chosen organizations. Due to convenience and researchers' contacts, two companies were chosen: one from the telecommunications sector (ALFA company), with already formalized IT architecture management; and another from the construction sector (BETA company), with IT architecture management in early stages of formalization.

In preparing the study protocol, the data collection process was explained by defining the unit of analysis, the criterion for choosing interviewees, the interview scripts, the creation of a data analysis report and the results validation process. Regarding the unit of analysis, Yin (2003) admits that case studies may involve more than one. In the case of this study, there will be two different units of analysis. As regards the objective of identifying and understanding IT architecture management practices, the analysis units are surveyed organizations themselves.

To meet the objective of identifying the influences of institutional and strategic factors, there will be a subdivision in which the units of analysis are the decisions taken regarding the architecture identified in each of the organizations. Interviewees in each of the companies were selected because they were involved in IT architecture decisions or had access to the arguments used in the choices. In company ALFA, we carried out interviews with seven managers, including the processes management field. In company BETA, because it is an organization whose IT infrastructure is very limited and mostly outsourced, we decided to carry out interviews with the IT director and two coordinators. Interviews were carried out in companies between March and August 2010.

Information was collected through interviews and analysis of the organization's documents. Two semi-structured scripts were used: one containing questions about the company's data, IT data, the organization's IT architecture data (history and development, major changes, current components) and its management (IT governance process, architecture management practices adopted, top management support, existing issues), applied only to the primary IT manager; and another containing questions about the interviewee's understanding of the IT architecture concept, IT architecture benefits and objectives, and questions about justifications and obstacles met in decisions about architecture (referring to business, information, applications or technology) of which the interviewee knew or in which he participated, the latter applied to all interviewees. The managers themselves chose the most important events according to their perception and data collection about the decisions went from there.

Since the two categories of influences can be considered antagonistic, according to Hrebiniak and Joyce (1985), the analysis of a particular factor according to its institutional origin or strategic choice should not be treated as if they were mutually exclusive categories. There is the possibility of analyzing if of one of them dominates within the acceptance of a continuum between the two extremes. It is possible to detect situations of great institutional and strategic influence, and other low institutional pressure and strategic performance phenomena too. This is the research design proposed by the paper, and it aims at giving conciliatory treatment to the two theories, as presented in Figure 1. The analysis method categorizes the decisions collected between strategic and institutional influences, as explained in the theoretical framework. 


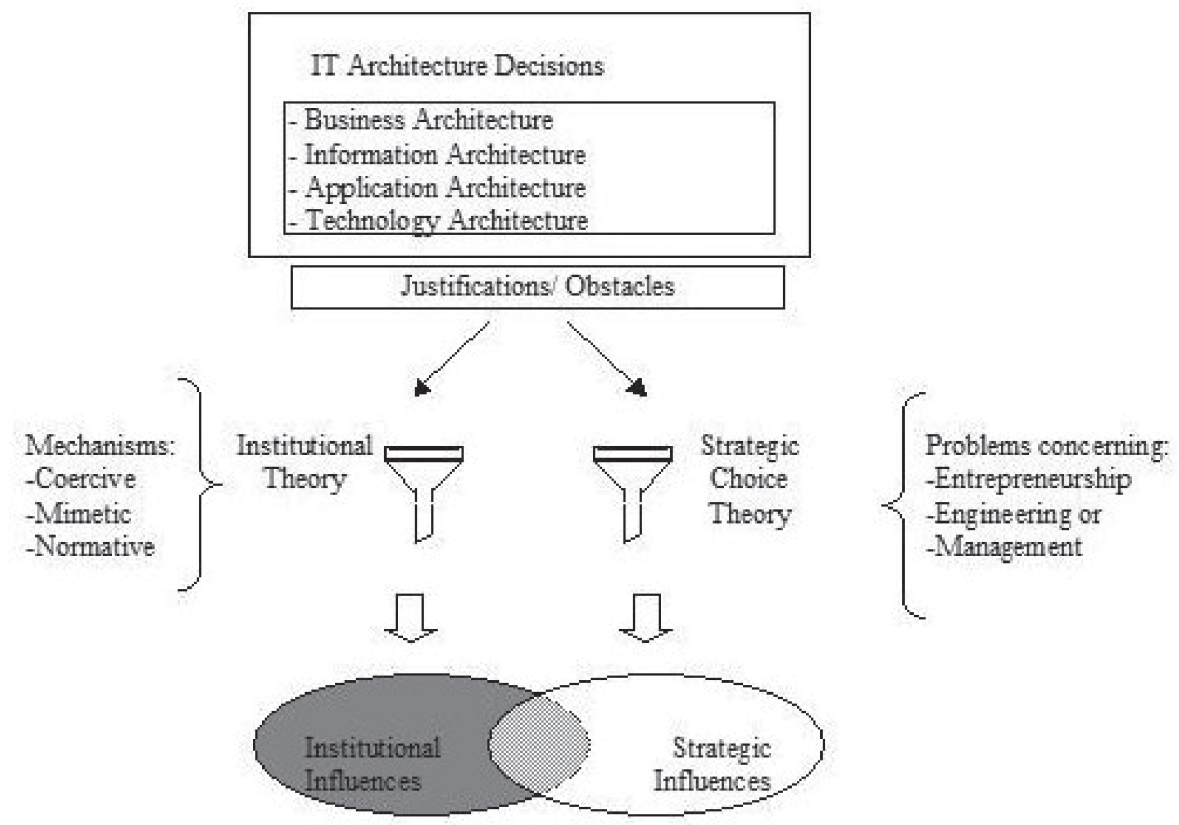

FIGURE 1 - Identification of institutional and strategic influences.

Source: the authors.

\section{CASESTUDIES-DATAPRESENTATION AND ANALYSIS}

\section{I Telecommunication Company Case (ALFA)}

Telecommunications company ALFA (a fictitious name) is a national private equity company offering pay-TV services via cable, broadband internet and voice over IP to the Brazilian market. Currently, the integrated range of services in the form of "packets" (services such as video, broadband, fixed-line or mobile) has been gaining increasing importance due to reducing costs for the final consumer, single charging and a perceived improvement in quality. Risks to the business are a high level of competition, rapid obsolescence of technology investment, high rates of subscriber disconnections, increases in programming costs, piracy, dependence on thirdparty services for customer service, and extensive government regulation (GIFFONI, MORAES, 2009).

The organization has undergone several changes in capital structure, since the beginning of operations in the 1990s, such as company acquisitions, divestitures, changes in equity control, structuring of subsidiaries in Brazilian cities, and sale of market shares in the United States and Brazil. Its annual gross revenue is about US\$ 4 billion, and it has 15,000 direct employees, as well as 12,000 indirect jobs. For each one of the three services offered, there are about 3 million subscribers. The company's IT division is divided into two boards that respond to the CIO: the Systems Development Directorate and the Infrastructure and Production Directorate, which manage the deployment and operation of systems. In the IT field, there are 132 direct employees and 621 contractors. The IT governance process is similar to the archetypes of most companies (WEILL, ROSS, 2004), in which architecture standards and infrastructure are the responsibility of IT, whereas decisions about IT principles, applications and investments involve other departments.

\section{I.I Evolution of IT Architecture in ALFA}

Between 2002 and 2004, hiring external consultants occurred; consultancy identified the 
need to enhance the experience of end-users during the sales, installation, maintenance, billing and cancellation processes. From there on, there was a redefinition of the company's main macroprocesses. In late 2006, several major projects in IT architecture were initiated: the certification of compliance with the Sarbanes - Oxley (SOX) Law, the deployment of Service Oriented Architecture (SOA), and the implementation of the framework enhanced Telecom Operations Map (eTOM) of the TeleManagement Forum (TM Forum), which is a telecommunications industry association that created models of best practices in IT architecture. The decision to adopt SOA occurred due to the fact that company ALFA's systems until 2006 were developed in a client-server platform with little modularity and did not offer enough flexibility to meet changing business demands. Moreover, due to the various acquisitions in previous years, there was a need to integrate with legacy systems, carried out by middleware systems, but focused on the problem and not on the technological understanding of the function of systems for business processes. In 2007, ALFA adopted eTOM to guide their decisions concerning business architecture. eTOM aims at being a process framework that can aid business modularity, define responsibilities and ensure interoperability between vendor solutions. All these events demanded efforts by various departments and constant senior management sponsorship.

\section{I.2 Management of IT Architecture in ALFA}

In ALFA, the management of IT architecture is decentralized into three managers within the IT infrastructure. Planning and support management is responsible for the architecture of hardware, software and database. Architecture management is responsible for application architecture and data modeling. A third IT security management is responsible for managing security architecture. With regard to business architecture, the design of processes is the responsibility of the organizational development directorate, with interface as to IT in Business
Process Management. The organization's IT architecture administrative practices include regular meetings between managements and within each management. A technical committee of architecture meets once a week and is made up of all managers involved with business architecture, information, applications and technology.

Decisions are published on the company's internal website, which includes manuals, best practices, standards and policies. One of the reasons for the documentation is to communicate designs and standardization to subcontractors. An architect follows each project and creates an architecture document that undergoes an approval process. Architecture exceptions must be approved and documented. There is also a quality control department in the IT field that uses software to verify adherence to standards and inconsistencies, especially concerning programming language. Due to the evolution of practices observed, according to the level of maturity of Ross, Weill and Robertson (2008), the organization presents characteristics belonging to three stages: standardized technology, optimized core and business modularity. Since it lacks processes' modularity and implemented the sharing of data and processes across the company, the best categorization for this company is the optimized core stage, the third of the scale.

\section{I.3 Meaning of IT Architecture for ALFA Managers}

The spontaneous answers of ALFA managers concerning the significance of IT architecture are outlined in Chart 1, together with their associated ideas. One can observe that, for this organization, IT architecture involves planning for the future, governance, standardization, and is also regarded as a communication and visualization tool for the current situation. Mentioned scopes include business, information, application and technology. Please observe that some responses distinguish between the business scope and the other scopes considered traditional within IT, such as information, 
application and technology, treating processes as a separate area. In a way, these answers are consistent with the management maturity of the IT architecture which the company occupies, since the organization considers its efficiency and flexibility important, carrying out initiatives to achieve them, such as the deployment of SOA and eTOM.

\begin{tabular}{|l|l|}
\hline IT Architecture according to managers & Associated ideas \\
\hline $\begin{array}{l}\text { "Includes business architecture, application, information, } \\
\text { infrastructure and production." }\end{array}$ & $\begin{array}{l}\text { IT architecture includes business, information, application and } \\
\text { technology architecture. }\end{array}$ \\
\hline $\begin{array}{l}\text { "IT planning for the future in terms of technology, infrastructure, } \\
\text { programming language, manufacturers, compliance to frameworks } \\
\text { (ITIL, COBIT), governance, hardware." }\end{array}$ & $\begin{array}{l}\text { Planning, Governance and Vision. } \\
\text { Includes application and technology architecture. Metaphor: } \\
\text { Architecture as a plan. }\end{array}$ \\
\hline $\begin{array}{l}\text { "Allows one to view all IT functionalities crossed with business, } \\
\text { systems management, processes and infrastructure functions." }\end{array}$ & $\begin{array}{l}\text { Vision. } \\
\text { IT architecture includes business, information, application and } \\
\text { technology architecture. } \\
\text { Metaphor: Architecture as literature. }\end{array}$ \\
\hline $\begin{array}{l}\text { "Architecture includes software, hardware, networking, security. It is } \\
\text { a communication method for the rest of the organization. It has to } \\
\text { be adapted to changing business needs and reflect the future model } \\
\text { that it wants to become." }\end{array}$ & $\begin{array}{l}\text { Planning, Governance and Vision. } \\
\text { Metaphor: Architecture as a plan, as literature and as language. }\end{array}$ \\
\hline $\begin{array}{l}\text { "Identifying new business needs." } \\
\text { "As is and to be models." }\end{array}$ & $\begin{array}{l}\text { Caters to the business strategy. } \\
\text { Includes business architecture. } \\
\text { Metaphor: Architecture as a plan. }\end{array}$ \\
\hline
\end{tabular}

CHART 1 - Meaning of IT architecture to ALFA managers

Source: The authors.

\section{I.4 IT Architecture decisions and Institutional and Strategic Influences in ALFA}

Chart 2 summarizes decisions referring to IT architecture mentioned spontaneously by ALFA managers and the year in which they were implemented. Decisions were classified according to their respective scopes and levels, following the scope classification of Ross, Weill and Robertson (2008) (business, information, application, technology) and the levels proposed by Pulkkinen (2006) (organization, domain and systems). They were classified as of strategic and/or institutional influence by researchers. All decisions were made for several institutional and strategic reasons. The last column of Chart 2 summarizes if institutional or strategic influence is most dominant, either due to emphasis by the interviewee or to qualitative assessment made by researchers. In some decisions, there was some difficulty to classify, so we concluded that there was a balance between the two influences. Charts 5 and 6 presented and described below, show examples of the explanations provided, grouped by theory and types of mechanism. 


\begin{tabular}{|l|l|l|l|l|}
\hline & Year & IT Architecture Decision & Scope/Level of architecture & $\begin{array}{l}\text { Most important } \\
\text { influence }\end{array}$ \\
\hline 1 & 2010 & $\begin{array}{l}\text { Contract with suppliers to manage the network instead of } \\
\text { hiring connections directly. }\end{array}$ & Technology / Organizational & Strategic \\
\hline 2 & 2010 & Control of employee access to internet & Application / Domain & Strategic \\
\hline 3 & 2010 & Virtualization of services in one application & Technology / Systems & Strategic \\
\hline 4 & 2006 & Change in programming language (from Net to Java) & Application / Domain & Strategic \\
\hline 5 & 2010 & Centralization of access to various systems & Application / Organizational & Strategic \\
\hline 6 & 2008 & Deployment of PMBOK Methodology for IT Projects & Business / Organizational & $\begin{array}{l}\text { Institutional and } \\
\text { Strategic }\end{array}$ \\
\hline 7 & 2010 & Hiring of external services based on business items & $\begin{array}{l}\text { Application and Technology / } \\
\text { Organizational }\end{array}$ & Strategic \\
\hline 8 & 2006 & SOA adoption & $\begin{array}{l}\text { Application and Technology/ } \\
\text { Organizational }\end{array}$ & $\begin{array}{l}\text { Institutional and } \\
\text { Strategic }\end{array}$ \\
\hline 9 & 2007 & Obtaining Sarbanes-Oxley certification & Business / Organizational & $\begin{array}{l}\text { Institutional and } \\
\text { Strategic }\end{array}$ \\
\hline 10 & 2010 & $\begin{array}{l}\text { Adoption of best practices model for managing IT } \\
\text { architecture by TM Forum }\end{array}$ & $\begin{array}{l}\text { Business, Application and } \\
\text { Information / Organizational }\end{array}$ & $\begin{array}{l}\text { Institutional and } \\
\text { Strategic }\end{array}$ \\
\hline
\end{tabular}

CHART 2 - IT architecture decisions according to ALFA managers

Source: The authors.

\subsection{Construction Company Case (BETA)}

Company BETA (fictitious name) belongs to the field of construction, specifically the real estate segment. Companies in this sector are exposed to various market risks: interest rates, economic slowdown, unemployment rates, inflation rates, production costs, income distribution policy and credit policy. In addition, there is a variation in the selling prices of enterprises, lack of a smooth production process, and the recent trend towards establishing partnerships for developing certain projects, since they may lead to sources of economic and commercial differences (TAVARES, 2008).

The company is family run and was founded nearly 30 years ago, working in the fields of development, construction and real estate services. Construction activity is the most important, investing in its own projects or through partnerships with third parties. It also possesses the incorporation field, which includes residential and commercial projects, and real estate activity, such as leasing and marketing. Because of the large variations in demand, a characteristic of the real estate market, most of the services are outsourced, since there are long periods of little activity and others with an intense demand for labor, especially for new projects. The organization has about 300 direct employees and 2.000 contractors. The IT unit harbors five direct employees and 15 contractors, plus the IT manager. The IT governance process establishes that IT architecture decisions and infrastructure are a responsibility of this department. Decisions concerning principles, applications and investments, involving the various business units - the archetype of duopoly, according to Weill and Ross (2004) - are divided between IT and top management. According to the company, the main regulations are legislation, construction methods, environmental laws and quality standards. These standards, however, hardly affect the IT field at all.

\subsection{Evolution of IT Architecture in BETA}

Recently, the company underwent a rapid growth process; together, the set of all work carried out over the last 30 years is equivalent to the activity of the year 2009, intending to multiply that number in subsequent years. In 2007, there was an initiative to modernize the company and 
professionalize top management, with an impact on all of the organization's departments.

In the IT field, the director of technology was hired to centralize management. As part of this modernization, in 2007 the purchase and implementation of an ERP was decided upon, becoming the main element of their architecture system. The previous legacy system, used to control the projects, and some isolated applications remain in use, connected to the ERP. According to Nascimento and Santos (2002), the penetration of IT in the construction industry is still small compared to other sectors, due to a number of barriers referring to professionals in the field, to long-established processes, to characteristics of the sector and to shortcomings in technology itself. These identified characteristics can be found in the organization of this case study. The importance of IT to the organization was only perceived after the deployment of the ERP; the need for an internal team was then acknowledged.

\subsubsection{Management of IT Architecture in BETA}

IT architecture decisions are concentrated on the IT director and his team. The task of formalizing processes belongs to another administrative area outside the IT department. Outsourcing is still present to offer flexibility when meeting the great variations of the construction business. The organization has few formalized specific IT architecture policies and has no full-time employees responsible for architecture management. The main identified practices within the company are: project design processes, some technological standardization policies, a construction IT management model, and attempts to formalize the IT architecture. Although there are efforts to formalize the most important decisions, such as planning and development guidelines for integration, they are still made considering not explicit principles. Recent changes in this company were the hiring of an director and ERP deployment, which integrated all information and transactions, typical characteristics of companies in the standardized technology stage, according to the level of maturity of Ross, Weill and Robertson (2008). Due to the lack of a formal integration policy, however, the organization has not yet fully reached this stage.

\subsubsection{Meaning of IT Architecture for BETA Managers}

The answers of BETA managers as to the meaning of IT architecture are in Chart 3. Amongst the four scopes of architecture (technology, information, application and business) technology and application were the most mentioned. Perhaps information architecture was not been mentioned because it is centered on ERP. The architecture of business processes probably had little relevance because the company is still in a preliminary stage of formalization. Other associations that were not mentioned are the ideas of planning, innovation, vision, principles and standardization. Just as in the case of company ALFA, BETA answers are consistent with the company's IT architecture management maturity.

\begin{tabular}{|l|l|}
\hline IT architecture according to managers & Associated ideas \\
\hline "Governance method" & Governance \\
\hline $\begin{array}{l}\text { "Diagram of the company, including the physical design of the } \\
\text { technological infrastructure for the purpose of documentation, } \\
\text { operational understanding and technical diagnostics" }\end{array}$ & $\begin{array}{l}\text { Includes architecture and technology } \\
\text { Metaphor: Architecture as literature, as language }\end{array}$ \\
\hline $\begin{array}{l}\text { "Construction of pillars such as security, infrastructure, system, } \\
\text { policies" }\end{array}$ & Includes application and technology architecture \\
\hline "Documentation for keeping knowledge within the company" & Metaphor: Architecture as literature \\
\hline $\begin{array}{l}\text { "Hardware and software infrastructure to contribute to business } \\
\text { improvement" }\end{array}$ & $\begin{array}{l}\text { Caters to business strategy } \\
\text { Includes application and technology architecture }\end{array}$ \\
\hline
\end{tabular}

CHART 3 - Meaning of IT architecture for BETA managers

Source: The authors. 


\subsubsection{IT Architecture decisions and Institutional and Strategic Influences in BETA}

Chart 4 summarizes IT architecture decisions identified in BETA. All decisions presented several institutional and strategic justifications. The last column of Chart 4 shows the type of influence that is dominant in every decision and some decisions were hard to classify, so we concluded that the two influences were registered. Charts 5 and 6, presented and described in the next section, detail the justifications provided.

\begin{tabular}{|c|c|c|c|c|}
\hline & Year & IT Architecture Decision & Scope/Level of architecture & $\begin{array}{l}\text { Most important } \\
\text { influence }\end{array}$ \\
\hline 1 & 2010 & Standardization of IT requests process & Business and Technology / System & Strategic \\
\hline 2 & 2008 & Adoption of SAP's ERP & Application as Information / Organization & $\begin{array}{l}\text { Institutional and } \\
\text { Strategic }\end{array}$ \\
\hline 3 & 2009 & $\begin{array}{l}\text { Standardization of ERP profiles } \\
\text { procedure }\end{array}$ & Business and Application / System & Strategic \\
\hline 4 & 2010 & Integration with $\mathrm{BI}$ & Application / System & Strategic \\
\hline 5 & 2009 & $\begin{array}{l}\text { IT management model for } \\
\text { construction work }\end{array}$ & $\begin{array}{l}\text { Business, Information, Application and Technology / } \\
\text { Domain }\end{array}$ & Strategic \\
\hline 6 & 2008 & Outsourcing policy & Application and Technology / Organization & Strategic \\
\hline 7 & 2009 & $\begin{array}{l}\text { Policies for use and acquisition of IT } \\
\text { in the organization }\end{array}$ & Application and Technology / Organization & Strategic \\
\hline 8 & 2010 & $\begin{array}{l}\text { Documentation of processes and } \\
\text { systems }\end{array}$ & Business and Application / Organization & Strategic \\
\hline 9 & 2009 & IT auditing & $\begin{array}{l}\text { Application, Information and Technology / Organiza- } \\
\text { tion }\end{array}$ & Strategic \\
\hline 10 & 2010 & New IT security structure & $\begin{array}{l}\text { Application, Information and Technology / Organiza- } \\
\text { tion }\end{array}$ & Strategic \\
\hline
\end{tabular}

CHART 4 - IT architecture decisions according to BETA managers

Source: The authors.

\section{ANALYSIS OF THE TWO CASES}

The case studies involve a large organization in the field of telecommunications (ALFA) and another midrange one belonging to the field of construction (BETA). Although they are from two different sectors, the two companies deal with high initial investments and presented high growth rates in the period surveyed. Companies present different stages of maturity according to the selection criteria of the cases itself. Company ALFA is in the optimized core stage, moving towards the business modularity due to its standardization, macro processes and centralization of data, whereas company
BETA is in the business silos stage, moving towards the standardized technology stage, according to Ross, Weill and Robertson (2008). In both companies, the IT department is responsible for the technology, application and information architecture. Business architecture, on the other hand, is the responsibility of another department within the two organizations, in a more decentralized model in company ALFA and a more centralized one in company BETA.

\section{I IT Architecture Meanings}

In company ALFA, the meaning of IT architecture was associated with planning, 
business architecture and strategic alignment between IT and business. When analyzing their management practices, we concluded that it valued aspects such as efficiency, quality and monitoring of core processes. Furthermore, observing the organizational structure, there is a process management within the IT department, which participates in the regular architecture meetings. Thus, business architecture is a part of the IT architecture, according to the answers of interviewees, and the idea that IT architecture includes catering to organizational goals is probably reflected in the practices of managers.

Moreover, in company BETA, neither business architecture nor its use as a means of planning were explicitly mentioned in the answers about the meaning of architecture. When carrying out the analysis of management practices, we concluded that the organization was between the business silos and the standardized technology stages, a phase in which architecture is not seen as a planning tool to promote strategic agility. Moreover, business processes do not formally have an interface with IT, corroborating that the meaning of architecture given by managers coincides with management practices and, consequently, with the company's stage of maturity. Thus, after analyzing the two cases, there is apparently no relationship between the meaning of IT architecture for managers and characteristics of their management, including the company's stage of maturity.

\subsection{Institutional and Strategic Influences on IT Architecture Decisions}

Chart 5 presents the justifications provided by corporate managers in ALFA and BETA for various decisions described in Charts 2 (ALFA) and 4 (BETA) which were related to institutional influences, classified according to the mechanisms proposed by DiMaggio and Powell (1983). The reason appears in the second (ALFA) and fourth (BETA) columns and the decisions for which they were mentioned are presented in the third (ALFA) and fifth columns (BETA) in the chart. Chart 6 presents the justifications provided by managers for the various decisions described in Charts 2 and 4, which were related to strategic choice influences, classified according to the adaptation issues proposed by Miles et al. (1978) (entrepreneurial, engineering and administration). 


\begin{tabular}{|c|c|c|c|c|}
\hline \multirow[b]{2}{*}{$\begin{array}{l}\text { Institutional } \\
\text { mechanism }\end{array}$} & \multicolumn{2}{|c|}{ Company ALFA } & \multicolumn{2}{|c|}{ Company BETA } \\
\hline & Justification presented & $\begin{array}{l}\text { Decision in which the } \\
\text { influence appears }\end{array}$ & Justification presented & $\begin{array}{l}\text { Decision in which the } \\
\text { influence appears }\end{array}$ \\
\hline \multirow{4}{*}{ Coercive } & Compliance with SOX & $\begin{array}{l}\text { Control of access to } \\
\text { internet and control of } \\
\text { centralized access, } \\
\text { PMBOK methodology }\end{array}$ & $\begin{array}{l}\text { Relationship with } \\
\text { supplier }\end{array}$ & Integration with BI \\
\hline & $\begin{array}{l}\text { American stock } \\
\text { Exchange requirement }\end{array}$ & SOX & $\begin{array}{l}\text { Helps justification for } \\
\text { obtaining financial } \\
\text { resources }\end{array}$ & IT auditing \\
\hline & $\begin{array}{l}\text { Company employees' } \\
\text { opinion }\end{array}$ & SOA & & \\
\hline & $\begin{array}{l}\text { To legitimate work and } \\
\text { divulge it }\end{array}$ & TM Forum Framework & $\begin{array}{l}\text { To obtain legitimacy in } \\
\text { the market }\end{array}$ & Adoption of SAP ERP \\
\hline \multirow{6}{*}{ Mimetic } & $\begin{array}{l}\text { Manager's prior ex- } \\
\text { perience within the } \\
\text { organization or in other } \\
\text { organizations }\end{array}$ & $\begin{array}{l}\text { Control of access to } \\
\text { internet, PMBOK } \\
\text { methodology }\end{array}$ & $\begin{array}{l}\text { Manager has already } \\
\text { used it in other com- } \\
\text { panies. }\end{array}$ & $\begin{array}{l}\text { Standardization of IT requests } \\
\text { process }\end{array}$ \\
\hline & Market trend & $\begin{array}{l}\text { Virtualization, } \\
\text { Framework TM Forum }\end{array}$ & Market practice & $\begin{array}{l}\text { Adoption of SAP ERP, policies } \\
\text { for use and acquisition of IT. IT } \\
\text { auditing. }\end{array}$ \\
\hline & $\begin{array}{l}\text { Help by suppliers or } \\
\text { consultancies }\end{array}$ & $\begin{array}{l}\text { Virtualization, SOA, } \\
\text { SOX }\end{array}$ & $\begin{array}{l}\text { Consultancy helped and } \\
\text { supplied models of best } \\
\text { market practices }\end{array}$ & $\begin{array}{l}\text { Standardization of ERP profiles } \\
\text { procedure }\end{array}$ \\
\hline & Adopted by industry & $\begin{array}{l}\text { Outsourcing business } \\
\text { items, TM Forum } \\
\text { Framework }\end{array}$ & & \\
\hline & $\begin{array}{l}\text { Cases of other } \\
\text { companies }\end{array}$ & $\begin{array}{l}\text { SOA, TM Forum } \\
\text { Framework }\end{array}$ & $\begin{array}{l}\text { Comparison with other } \\
\text { companies' indexes }\end{array}$ & $\begin{array}{l}\text { Documentation of processes } \\
\text { and systems }\end{array}$ \\
\hline & Considered modern & TM Forum Framework & & \\
\hline Normative & $\begin{array}{l}\text { Consensus in field of } \\
\text { work }\end{array}$ & $\begin{array}{l}\text { Control of centralized } \\
\text { access, TM Forum Fra- } \\
\text { mework }\end{array}$ & $\begin{array}{l}\text { Participation in con- } \\
\text { gresses to compare with } \\
\text { Opinion of specialists }\end{array}$ & Adoption of SAP ERP \\
\hline
\end{tabular}

CHART 5 - Reported IT architecture decisions in ALFA and BETA

Source: The authors.

The two companies presented influences by institutional and strategic factors. For company ALFA, in decisions 1, 2, 3, 4, 5 and 7 presented in Chart 2, strategic motivations were identified as dominant. These decisions had a more limited scope, with tools that were familiar to managers and solutions matured in the market itself. Decisions 6, 8, 9 and 10, on the other hand, presented emphasis on institutional influences, especially the adoption of the TM Forum frameworks (decision 10). Since all decisions presented at least some strategic motivation, we can conclude that the strategic arguments were most often mentioned than institutional motivations as influences in decisions in company ALFA. 


\begin{tabular}{|c|c|c|c|c|}
\hline & \multicolumn{2}{|c|}{ Company ALFA } & \multicolumn{2}{|r|}{ Company BETA } \\
\hline Issue & $\begin{array}{l}\text { Justification } \\
\text { presented }\end{array}$ & $\begin{array}{l}\text { Decision in which the } \\
\text { influence appears }\end{array}$ & $\begin{array}{l}\text { Justification } \\
\text { presented }\end{array}$ & Decision in which the influence appears \\
\hline \multirow{3}{*}{ Entrepreneurship } & $\begin{array}{l}\text { To support growth/ } \\
\text { evolution }\end{array}$ & $\begin{array}{l}\text { TM Forum Framework, } \\
\text { change in programming } \\
\text { language. }\end{array}$ & $\begin{array}{l}\text { Adaptation for future } \\
\text { company growth }\end{array}$ & $\begin{array}{l}\text { Standardization of ERP profiles } \\
\text { procedure, New IT security } \\
\text { structure }\end{array}$ \\
\hline & $\begin{array}{l}\text { Strategic } \\
\text { relationships with } \\
\text { suppliers }\end{array}$ & $\begin{array}{l}\text { Change in programming } \\
\text { language } \\
\text { (to a non-proprietor). }\end{array}$ & & \\
\hline & Flexibility & $\begin{array}{l}\text { SOA, hiring based on business } \\
\text { items }\end{array}$ & & \\
\hline \multirow{6}{*}{ Engineering } & \begin{tabular}{|l|} 
Process \\
standardization
\end{tabular} & $\begin{array}{l}\text { PMBOK methodology, TM } \\
\text { Forum Framework }\end{array}$ & Greater security & $\begin{array}{l}\text { Standardization of ERP profiles } \\
\text { procedure }\end{array}$ \\
\hline & Integration & SOA & $\begin{array}{l}\text { Integration with existing } \\
\text { systems }\end{array}$ & Integration with BI \\
\hline & Tool for guidance & TM Forum & $\begin{array}{l}\text { Better quality and better } \\
\text { solution }\end{array}$ & Outsourcing policy \\
\hline & Reuse & SOA & Standardization & $\begin{array}{l}\text { Policies for use and acquisition of IT in } \\
\text { the organization, IT } \\
\text { management model for } \\
\text { construction work, Standardization of } \\
\text { ERP profiles procedure. }\end{array}$ \\
\hline & Increase in capacity & $\begin{array}{l}\text { Network management } \\
\text { contract. Control of access to } \\
\text { internet, SOA. }\end{array}$ & Increase in capacity & $\begin{array}{l}\text { Standardization of ERP profiles } \\
\text { procedure }\end{array}$ \\
\hline & $\begin{array}{l}\text { Performance } \\
\text { improvement }\end{array}$ & $\begin{array}{l}\text { Change in programming } \\
\text { language; Virtualization. }\end{array}$ & Performance & New IT security structure \\
\hline \multirow{9}{*}{ Administration } & Cost reduction & $\begin{array}{l}\text { Network management } \\
\text { contract, control of access to } \\
\text { internet, virtualization, hiring } \\
\text { based on business items, SOA }\end{array}$ & $\begin{array}{l}\text { Control suppliers' SLA } \\
\text { when } \\
\text { implementing } \\
\text { internal index } \\
\end{array}$ & $\begin{array}{l}\text { Standardization of IT } \\
\text { requests process } \\
\text { Outsourcing policy }\end{array}$ \\
\hline & $\begin{array}{l}\text { To ease } \\
\text { management/ } \\
\text { operation }\end{array}$ & $\begin{array}{l}\text { Network management } \\
\text { contract, virtualization. }\end{array}$ & $\begin{array}{l}\text { Control of performance } \\
\text { and time of reaction. }\end{array}$ & Standardization of IT requests process \\
\hline & $\begin{array}{l}\text { Control of IT } \\
\text { and employees }\end{array}$ & $\begin{array}{l}\text { Control of access to } \\
\text { internet, SOX. }\end{array}$ & Lower cost & Integration with BI \\
\hline & $\begin{array}{l}\text { Precise } \\
\text { information }\end{array}$ & $\begin{array}{l}\text { Control of access to } \\
\text { internet, SOX. }\end{array}$ & $\begin{array}{l}\text { Protects the company } \\
\text { when employees are } \\
\text { substituted }\end{array}$ & Outsourcing policy \\
\hline & Time reduction & $\begin{array}{l}\text { Centralized control of } \\
\text { access, SOA. }\end{array}$ & $\begin{array}{l}\text { Defining users' } \\
\text { responsibilities }\end{array}$ & $\begin{array}{l}\text { Policies for use and acquisition } \\
\text { of IT }\end{array}$ \\
\hline & \begin{tabular}{|l|}
$\begin{array}{l}\text { Bureaucracy } \\
\text { reduction }\end{array}$ \\
\end{tabular} & Centralized control of access & $\begin{array}{l}\text { Legal protection of the } \\
\text { organization }\end{array}$ & $\begin{array}{l}\text { Policies for use and acquisition } \\
\text { of IT }\end{array}$ \\
\hline & Monitoring & Centralized control of access & $\begin{array}{l}\text { Possibility of } \\
\text { improving processes }\end{array}$ & $\begin{array}{l}\text { Documentation of processes } \\
\text { and systems }\end{array}$ \\
\hline & & & $\begin{array}{l}\text { Visualization and } \\
\text { diagnosis of the IT field }\end{array}$ & IT auditing \\
\hline & & & $\begin{array}{l}\text { Consolidation of } \\
\text { information }\end{array}$ & Integration with $\mathrm{BI}$ \\
\hline
\end{tabular}

CHART 6 - Reported strategic IT architecture decisions in ALFA and BETA

Source: The authors.

In company BETA, the only decision in which an important institutional argument was raised was the adoption of the new ERP (Decision 2 in Chart 4). In all others, the greatest influence in the justifications of managers was strategic, characterizing the dominance of this type of justification, just as in ALFA.

An interesting fact is that decisions involving innovation, greater risks and more comprehensive in organizational amplitude presented more institutional factors, mainly related to a mimicry mechanism in both companies. In company ALFA, decisions 6, 8,9 and 10 are in this category and address PMBOK methodology, SOA, SOX and TM Forum frameworks, whereas in company BETA, decision 2, ERP implementation, also has these characteristics and presented institutional influences in the justifications demonstrated. 
In ALFA, perhaps the main highlight is the institutional need to meet regulatory requirements of the stock exchange (SOX) and the importance given to the criterion flexibility as a strategic factor, whereas in BETA IT is less affected by regulation. Another common feature between the two is that the major IT initiatives, such as implementation of macro processes, SOA and TM Forum models (by company ALFA) and the adoption of the new ERP (company BETA) were probably preceded by external changes in the market and consequently in organizational strategy. Chart 7 shows the summary of the comparison between the two companies' architectures and justifications.

\begin{tabular}{|c|c|c|}
\hline & Telecommunications company & Construction company \\
\hline IT architecture maturity stage & $\begin{array}{l}\text { Optimized core stage with initiatives towards } \\
\text { business modularity stage. }\end{array}$ & $\begin{array}{l}\text { State between business silos and standardized } \\
\text { technology. }\end{array}$ \\
\hline $\begin{array}{l}\text { Practices that contributed } \\
\text { so it reaching present stage } \\
\text { of maturity }\end{array}$ & $\begin{array}{l}\text { Deployment of macro processes, data } \\
\text { centralization project and adoption of SOA to } \\
\text { allow for modularity of the systems infrastructure. }\end{array}$ & $\begin{array}{l}\text { Hiring of IT team to centralize decisions, ERP } \\
\text { deployment. }\end{array}$ \\
\hline $\begin{array}{l}\text { Architecture and } \\
\text { Technology }\end{array}$ & $\begin{array}{l}\text { Standardization through policies and decisions } \\
\text { in the field of IT formalized and divulge. A great } \\
\text { deal outsourced. }\end{array}$ & $\begin{array}{l}\text { Certain standardization through policies and } \\
\text { decisions in the IT field. Greatest part outsourced. }\end{array}$ \\
\hline Applications architecture & $\begin{array}{l}\text { Integration through SOA. Planning of evolution } \\
\text { of applications according to TM Forum models. }\end{array}$ & $\begin{array}{l}\text { Tendency to choose applications which easily inte- } \\
\text { grate with ERP, such as applications from the same } \\
\text { supplier. }\end{array}$ \\
\hline Information architecture & There was a data centralization process & $\begin{array}{l}\text { Most of the data centralized in ERP. Data is inside } \\
\text { applications. There is some information in the } \\
\text { intranet portal and in shared directories. }\end{array}$ \\
\hline Business architecture & $\begin{array}{l}\text { Organization in macro processes. Recent initiative } \\
\text { of adopting of TM Forum eTOM model. }\end{array}$ & Recent initiative of process documentation. \\
\hline $\begin{array}{l}\text { Coactive institutional } \\
\text { justifications }\end{array}$ & $\begin{array}{l}\text { - Compliance with SOX } \\
\text { - Company employees' opinion } \\
\text { - Legitimating work and its diffusion } \\
\text { - Considered modern }\end{array}$ & $\begin{array}{l}\text { - Obtaining market legitimacy } \\
\text { - Relationship with supplier } \\
\text { - Help in justification for obtaining financial } \\
\text { resources }\end{array}$ \\
\hline $\begin{array}{l}\text { Mimetic institutional } \\
\text { justifications }\end{array}$ & $\begin{array}{l}\text { - Prior experience of manager within the } \\
\text { organization or in other organizations } \\
\text { - Help of suppliers or consultancies } \\
\text { - Market practice }\end{array}$ & $\begin{array}{l}\text { - Manager has already used it in other companies } \\
\text { - Help of consultancy } \\
\text { - Market practices } \\
\text { - Comparison with other companies' indexes }\end{array}$ \\
\hline $\begin{array}{l}\text { Normative institutional } \\
\text { justifications }\end{array}$ & - Consensus in the field of work & $\begin{array}{l}\text { - Participation in congresses to compare with } \\
\text { specialists' opinions }\end{array}$ \\
\hline $\begin{array}{l}\text { Strategic justifications for } \\
\text { entrepreneurship issues }\end{array}$ & $\begin{array}{l}\text { - Strategic relationships with suppliers } \\
\text { - Flexibility } \\
\text { - Support to growth/evolution }\end{array}$ & $\begin{array}{l}\text { - Adaptation for the future growth of the } \\
\text { organization }\end{array}$ \\
\hline $\begin{array}{l}\text { Strategic justifications for } \\
\text { engineering issues }\end{array}$ & $\begin{array}{l}\text { - Capacity, performance } \\
\text { - Standardization } \\
\text { - Integration } \\
\text { - Reuse }\end{array}$ & $\begin{array}{l}\text { - Capacity, performance } \\
\text { - Standardization } \\
\text { - Integration } \\
\text { - Security and quality } \\
\end{array}$ \\
\hline $\begin{array}{l}\text { Strategic justifications for } \\
\text { administration issues }\end{array}$ & $\begin{array}{l}\text { - Reduction of costs, time. } \\
\text { - Control of employees and IT } \\
\text { - Precise information }\end{array}$ & $\begin{array}{l}\text { - Reduction of costs } \\
\text { - Control of employees and IT } \\
\text { - Information consolidation } \\
\text { - Way of controlling SLA of suppliers and internal } \\
\text { - Legal protection of the organization }\end{array}$ \\
\hline $\begin{array}{l}\text { Comparison between } \\
\text { institutional and strategic } \\
\text { justifications }\end{array}$ & $\begin{array}{l}\text { Strategic motivation occurs in all } \\
\text { decisions. This motivation is dominant in } \\
\text { most answers. In decision involving greater } \\
\text { risks, referring to the whole organization, } \\
\text { institutional justifications come up more } \\
\text { frequently, at various levels. }\end{array}$ & $\begin{array}{l}\text { Strategic motivation occurs in all decisions. This } \\
\text { motivation is dominant in most answers. The } \\
\text { only decision that seemed to include a little } \\
\text { institutional influence was adoption of new ERP. }\end{array}$ \\
\hline
\end{tabular}

CHART 7 - Summary of IT architecture management and justifications

Source: The authors. 
Several institutional and strategic justifications in the answers are in line with studies on the benefits of IT architecture. We observed that most strategies are in the literature review presented by Tamm et al. (2011). The institutional ones are not identified as direct benefits in the literature review, but are presented as quality criteria for architecture. In reviewing MacLennan and Van Belle (2013), the strategic justifications in this article appear in the literature review, usually as technological and organizational factors, whereas some institutional ones appear in the environmental factor, such as encouragement of industry and suppliers.

\section{CONCLUSIONS}

This research allowed us to illustrate, through case studies, IT architecture management aspects in companies at different stages of maturity and emphasis on strategic arguments in decisions related to it. Through study of the two cases, it was possible to understand relevant management practices to assist in the evolution of stages of maturity of IT architecture (business silos, standardized technology, optimized core and business modularity). We concluded that, in the case of company BETA, the initiative to formalize through documentation, ERP deployment and centralized management team can lead an organization from the business silos stage to the next. In the case of company ALFA, the adoption of models of industry associations processes standardization, such as TM Forum, theoretically has the potential to take it to the stage of business modularity. A point highlighted by several testimonies of the two organizations was that many of the management practices were adopted primarily for the purpose of controlling the activities of contractors, benefiting also the control of internal activities.

We found a relationship between the meaning of IT architecture for interviewees and the way their management is carried out in the company (their maturity). In company BETA technology and application architectures were mentioned, whereas, in company ALFA, the four (business, information, application and technology) were remembered by many managers, reflecting the greater degree of understanding of the role of IT architecture in the company. One similarity between the two companies concerning this item is the fact that different managers within the same organization have no consensus on the definition of the scope in which IT architecture acts, even in company ALFA.

We concluded that strategic motivations appeared in all decisions and were clearly dominant in the majority of cases in both companies. Decisions with balanced combination of institutional and strategic arguments appeared in the two organizations, especially in the most important initiatives at organizational level, involving major uncertainties and risks. Only two decisions, one in each company, harbored stronger mimetic institutional justifications which, coincidentally, were associated with the core elements of IT architecture in that organization.

Oliver (1988) showed, in a quantitative study, that the strategic justifications excel in strategic organizational decisions, but his research studied companies as a whole and not only the IT department, as we did in this paper. Therefore, the contribution of this research is that it used a different methodology to try to corroborate this same result and was able to show that strategic justifications are also mentioned more frequently in decisions about IT architecture. The stage of maturity of the company is probably not related to this, since, in both companies, institutional influences appear in decisions where there is greater uncertainty and risk.

Perhaps there are differences about the reasons behind institutional factors: the more mature, probably, due to their capital structure and possibility of influencing standards; and the less mature probably by resource constraints. Perhaps the most interesting revelation was the fact that the institutional mechanisms, especially mimetic ones, are present in organizational level decisions related to innovation, dealing with a higher level of uncertainty. 
Regarding strategic motivations, control of outsourced activities was identified as an important motivator of several initiatives, later benefiting control of internal activities. Furthermore, the solution of administrative and technical problems arising from the company's growth also motivated actions in architecture. Therefore, operational structure and growth prospects may be important issues in the process of decision making.

Another interesting observation is that strategic justifications were recognized in studies in the literature review as factors that led to IT architecture decisions. Institutional justifications, however, usually do not appear or are mentioned only indirectly in the articles.

As a limitation of the study, we can highlight the fact that carrying it out in only two companies prevents, in principle, the generalization of results, because of the qualitative methodology of case studies adopted, whose aim is not statistical generalization. In addition, interviewees themselves and literature have suggested that there is a difference of expectations and demand for information in the two kinds of industry, which can alter the results. The studied companies, however, were chosen so that they represent two different stages of maturity, allowing for the generation of new hypotheses, variables and factors for the feasibility of future studies. Another limitation is related to the process of categorizing justifications as institutional or strategic, by classifying ideas in the spontaneous answers of managers. In a further review of the answers, however, we observe that institutional arguments may represent expectations of strategic outcomes, though these are not explicit at first.

\section{REFERENCES}

CHILD, J. Strategic choice in the analysis of action, structure, organizations and environment: retrospect and prospect. Organization Studies, Berlin, v. 18, n. 1, p. 43-76, Winter 1997.
UNITED STATES. Department of Commerce. Office of the Chief Information Officer. Information technology architecture: what is it, why should you care and how do you do one? 2004. Available at: <http://ocio.os.doc. gov/s/groups/public/@doc/@os/@ocio/@oitpp/ documents/content/prod01_002345.pdf>. Access on: 20 Apr. 2009.

DESANCTIS, G.; POOLE, M. Capturing the complexity in advanced technology use: adaptive structuration theory. Organization Science, Minneapolis, v. 5, n. 2, p. 121-147, May 1994.

DIMAGGIO, P. J.; POWELL, W. W. The iron cage revisited: institutional isomorphism and collective rationality in organizational fields. American Sociological Review, Washington DC, v. 48, n. 2, p. 147-160, Apr. 1983.

GIFFONI, S. T. A.; MORAES, R. O. Convergência tecnológica e estratégias genéricas em empresas de telecomunicações. Revista Eletrônica de Sistema de Informaçáo, Curitiba, v. 8 , n. 1, p. 1-22, jan./jun. 2009. Available at <http://revistas.facecla.com.br/index.php/reinfo/ article/view/266/390>. Access on: 20 Apr. 2009.

HREBINIAK, L. G.; JOYCE, W. F. Organizational adaptation: strategic choice and environmental determinism. Administrative Science Quarterly, Ithaca, v. 30, n. 3, p. 336-349, Sept. 1985.

LEGANZA, G. Topic review: enterprise architecture. [S.1.]: Forrester, 2007.

MACLENNAN, E.; VAN BELLE, J. P. Factors affecting the organization adoption of service oriented architecture (SOA). Information Systems and e-Business Management, Heidelberg, Jan. 2013. Available at: <http:// link.springer.com/article/10.1007/s10257-0120212-x>. Access on: 08 Sept. 2013.

MILES, R. E. et al. Organizational strategy, structure and processes. The Academy of Management Review, Briarcliff Manor, v. 3, n. 3, p. 546-562, Jul. 1978. 
NASCIMENTO, L. A.; SANTOS, E. T. Barreiras para o uso da tecnologia da informação na indústria da construção civil. In: WORKSHOP NACIONAL DE GESTÁO DE PROCESSO NA CONSTRUÇÃO DE EDIFÍCIOS, 2., 2002, Porto Alegre. [Anais eletrônicos...] Porto Alegre: PUC, 2002. Available at: <http://www.eesc.usp. $\mathrm{br} / \mathrm{sap} / \mathrm{projetar} /$ files/A015.pdf $>$. Access on: 08 Sept. 2013.

OLIVER, C. The collective strategy framework: an application to competing predictions of isomorphism. Administrative Science Quarterly, Ithaca, v. 33, n. 4, p. 543-561, Dec. 1988.

Sustainable competitive advantage: combining institutional and resource based view. Strategic Management Journal. Toronto, v. 18, n. 9, p. 697-713, Oct. 1997.

ORLIKOWSKI, W. J.; BARLEY, S. R. Technology and institutions: what can research on information technology and research from organizations learn from each other. MIS Quarterly, Minneapolis, v. 25, n. 2, p. 145-165, June 2001.

POWELL, W. W.; DIMAGGIO, P. J. The new institutionalism in organizational analysis. Chicago: University of Chicago Press, 1991.

PULKKINEN, M. Systemic management of architectural decisions in enterprise architecture planning: four dimensions and three abstraction levels. In: HAWAII INTERNATIONAL CONFERENCE ON SYSTEM SCIENCES, 39., 2006. Hawaii. Proceedings... [Hawaii]: IEEE, 2006. p. 179a.

RADEKE, F. Awaiting explanation in the field of enterprise architecture management. In: AMERICAS CONFERENCE ON INFORMATION SYSTEMS, 16., 2010. Lima. Proceedings... [Lima: S.n.], paper 442, 2010.

ROSS, J. W.; WEILL, P.; ROBERTSON, D. C. Arquitetura de TI como estratégia empresarial. São Paulo: Makron Books, 2008.
SMOLANDER, K. Four metaphors of architecture in software organizations: finding out the meaning of architecture in practice. In: INTERNATIONAL SYMPOSIUM ON EMPIRICAL SOFTWARE ENGINEERING, 2002. Proceedings... [S.1.]: IEEE, 2002, p. 211-221.

TAMM, T. et al. How does enterprise architecture add value to organizations? Communications of the Association for Information Systems, [S.1.], v. 28, n.1, p. 141-168, Mar. 2011.

TAVARES, R. A estrutura de financiamento das empresas brasileiras abertas do setor de construçáo civil incorporadora de empreendimentos imobiliários: um estudo comparativo. 2008. 160 f. Tese (Doutorado em Administração) - Faculdade de Economia, Administração e Contabilidade, Universidade de São Paulo, São Paulo, 2008.

THOMSON REUTERS. Web of Science. 2013. Available at: <http://apps. webofknowledge.com/WOS_GeneralSearch_ input.do?product $=$ WOS \&highlighted_ tab $=$ WOS \&search_mode $=$ GeneralSearch $>$. Access on: 08 Sept. 2013.

VICENTE-LORENTE, J. D. ; ZÚNIIGAVICENTE, J. A. Testing the time-variance of explanatory factors of strategic change. British Journal of Management, Oxford, v. 17, n. 2, p. 93-114, June 2006.

WEILL, P.; ROSS, J. W. IT governance: how top performers manage IT decision rights for superior results. Boston: Harvard Business School Press, 2004.

YIN, R. K. Estudo de caso: planejamento e métodos. 2. ed. Porto Alegre: Bookman, 2003.

ZACHMAN, J. A. Enterprise architecture: the issue of the century. Database Programming and Design Magazine, [S. 1.], p. 1-14, Mar. 1997.

ZUCKER, L. G. Institutional theories of organization. Annual Review of Sociology, Los Angeles, v. 13, p. 443-464, 1987. 